Portland State University

PDXScholar

1975

\title{
Pretesting a questionnaire at the Solo Center on the impact of divorce on children and parents
}

Shirley Anne Paetzhold

Portland State University

Follow this and additional works at: https://pdxscholar.library.pdx.edu/open_access_etds

Part of the Child Psychology Commons, Social Welfare Commons, and the Social Work Commons Let us know how access to this document benefits you.

\section{Recommended Citation}

Paetzhold, Shirley Anne, "Pretesting a questionnaire at the Solo Center on the impact of divorce on children and parents" (1975). Dissertations and Theses. Paper 1796.

https://doi.org/10.15760/etd.1795

This Thesis is brought to you for free and open access. It has been accepted for inclusion in Dissertations and Theses by an authorized administrator of PDXScholar. Please contact us if we can make this document more accessible: pdxscholar@pdx.edu. 
PRETESTING A QUESTIONNAIRE AT THE SOLO CENTER

ON

THE IMPACT OF DIVORCE ON CHILDREN AND PARENTS

by

$\overrightarrow{S H I R L E Y ~ A N N E ~ P A E T Z H O L D ~}$

\author{
A PRACTICUM \\ submitted to \\ PORTILAND STATE UNIVERSITY
}

in partial fulfillment of

the requirements for the

degree of

MASTER OF SOCIAI WORK

1975 
To The Office of Graduate Studies:

Approval is granted to the practicum of

Shirley A. Paetzhold presented May 30, 1975:

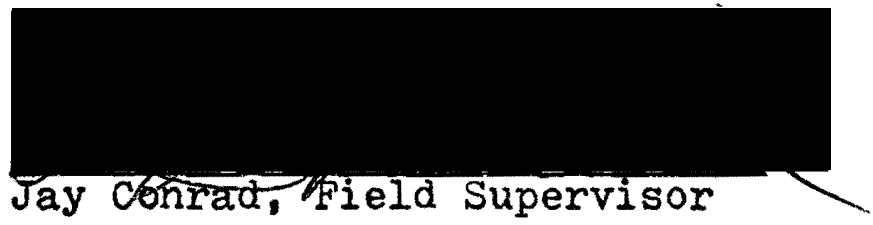




\section{ACKNOWLEDGMENTS}

I wish to express my deep and sincere appreciation to Dr. Stanley Cohen, Assistant Professor in the Department of Psychiatry and Pediatrics, University of Oregon Medical, School and Nolan Jones, Research Assistant, and the other members of the IDCAP project team for the opportunity to work with them. Their interest, and the time and expertise which they shared with me, were an essential ingredient in producing this paper. It was a stimulating opportunity to take a part in the planning and implementation of an extremely important and challenging research project, which has many far-reaching implications in the field of Social Work.

I also wish to acknowledge Jay Conrad, Field Supervisor for the Community Mental Health Project. His support, interest, and suggestions were vitally important in the final direction and focus of this study.

Furthermore, I would like to acknowledge Betty Daggett, M.S.W., Director of the Solo Center for her interest and cooperation during my pretest of the IDCAP questionnaire at the Center. She also provided me with valuable background information on the center and on her philosophy in creating the Solo Center. 


\section{IIST OF TABLES}

TABIE

PAGE

1 Distribution by Age and Duration of Marriage - . 18

2 Distribution by Sèx and Time Lapse Since Divorce . 19

3 Classification by Level of Agreement . . . . . 20

4 Level of Agreement Related to Sex and Monthly Income .. . . . . . . . . . . . . 21 
TABLE OF CONTENTS

PAGE

ACKNOWLEDGMENTS . . . . . . . . . . . . i i . .

LIST OF TABLES . . . . . . . . . . . . . iv

TABLE OF CONTENTS .................. . . v

INTRODUCTION ...................... I

THE SOLO CENTER ............... . . 2

IDCAP . . . . . . . . . . . . 9

METHODOLOGY ................ 15

GENERAI OBSERVATIONS ON SUBJECTS INTERVIEWED . . 22

: Custody ................ 2 24

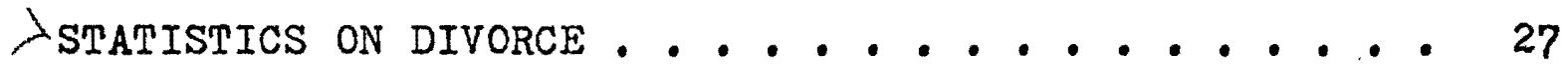

BACKGROUND . . . . . . . . . . . . . 29

FORCES OF CHANGE ............ 34

THE WOMEN'S MOVEMENT AND CHANGING ROLES . . . 35

CONCLUSION ........................... 41

BIBLIOGRAPHY ...................... 44

FOOTNOTES . . . . . . . . . . . . 49

APPENDIX A . . . . . . . . . . . 51

APPENDIX B .................... 60 


\section{INTRODUCTION}

This study was concerned with the impact of divorce on parents and children. The writer spent a minimum of sixteen hours per week from September, 1974 to May, 1975 in field work at the Solo Center, as part of the requirements for a Master's Degree in Social Work at Portland State University. Multiple areas of interest for research at the Center narrowed to a focus on the closely interwoven problems of child custody, child support, and visitation.

During the early stages of this research, a fortuitous interview with Dr. Stanley Cohen, Associate Professor in the Department of Psychiatry and Pediatrics at the University of Oregon Medical School led to a cooperative effort. The writer joined Dr. Cohen's research project, identified as IDCAP (Impact of Divorce on Children and Parents.) The research portion of this project had been funded, and a team was being developed. In collaboration with Nolan Jones, Research Assistant on the project, the writer spent many hours in developing a questionnaire and interview schedule under the tutelage of Dr. Cohen. The entire team met at weekly intervals for review and critical appraisal of the instrument. It was agreed that upon completion of a satisfactory instrument, a pretest would be conducted at the solo Center. This pretest would be in the service of determining the degree of efficiency it evinced in reaching information 
needed in the first step of a controlled, longitudinal study being implemented by the IDCAP team. Additions and refinements were made in the instrument, based on feedback from the pretesting operation.

This involvement was highly influential on the writer's thinking and attitudes toward possible means of intervention that could occur early in the divorcing process. These interventions would hopefully minimize the deleterious effects of the impact of the divorce process on both parents and children. Another stimulating result occurred through introduction to a conflict management framework as a means of understanding the inevitable differences that arise in close interpersonal relationships.

\section{THE SOLO CENTER}

The Solo Center is a unique experiment, operating as a resource center for single adults. Approximately 95\% of the persons using the Center are single by divorce.

The Center is located in a homelike setting in a large house in Northeast Portland. Betty Daggett, M.S.W., Director of the Solo Center, was the driving force behind the implementation of an idea to provide a new service in the community. Active involvement in planning and producing a series: "The Challenge of Divorce" as an educational event sponsored by the Metro Mental Health Association sparked her interest in a need for an ongoing service to 
single adults. The Divorce Series was first presented in 1968 and became a yearly event. Each year it became more apparent to those involved that additional support was needed. The population of singles was growing, and the response to the annual Divorce Series reflected that increase.

Newly single individuals and those in the process of becoming single are faced with multiple changes in their lives and critical decisions to make, beclouded by an aura of personal failure. Even though our society is becoming more tolerant of divorce, it still carries the onus of personal failure.

William Goode, in his book After Divorce, suggests that at least some of the extreme tension which surrounds almost every aspect of divorce may be created by the ambiguity of the divorce process in our culture. He points out

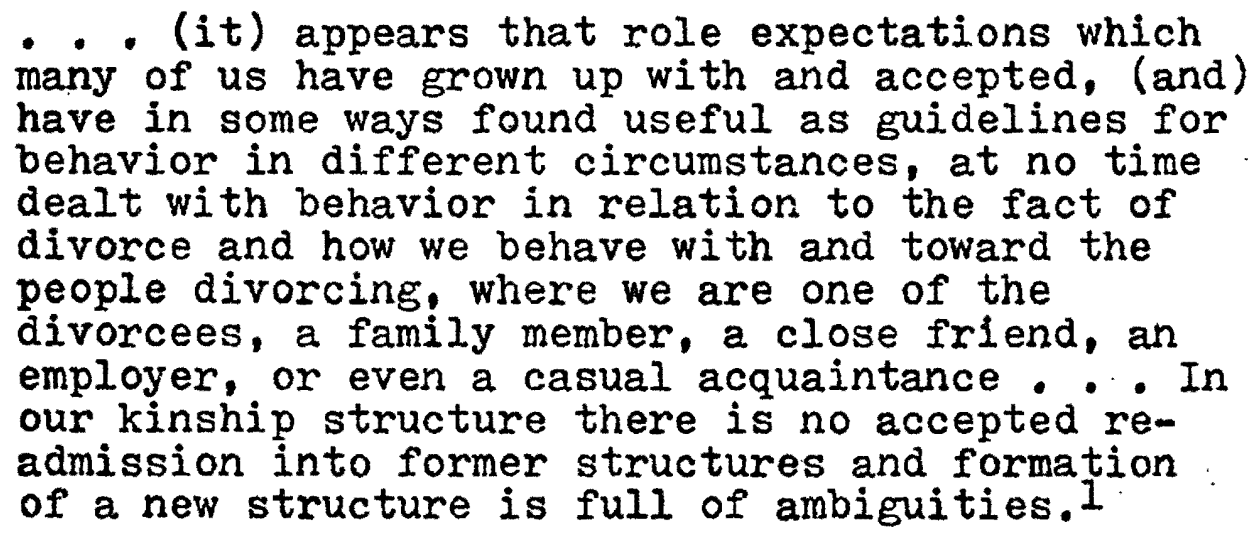

In fact, it has been noted that many people never have lived autonomously as single adults. They moved from living in the household of their family of origin into 
living as part of a couple in a marriage relationship.

The Solo Center opened its doors in November, 1973 with no source of funding but with the help of a very dedicated group of people who were totally convinced its time had come. Verification of that conviction is revealed by the number of single men and women using its services. Growth has been much more rapid than anticipated and has been a continuing force on the staff to keep up with and respond to the demands.

Records indicate a count of 416 individuals, making 1278 different uses of the Center for the month of March 1975. It is anticipated this figure will continue to rise as the Solo Center develops new services which can be made available during the daytime hours. Presently, the majority of use is during the evening hours, and the present numbers of people using the Center in the evening are reaching the maximum feasible for the present facility.

The Solo Center offers lectures, rap sessions, seminars, workshops, counseling, and informal socializing. This variety of opportunities to participate provides different levels of support in a uniquely flexible response to different levels of need. The design of the Center operation demands many hours of volunteer time. It is open from 10:30 a.m. until approximately 11:00 p.m. five days a week and from 1 p.m. until around midnight on weekends. This need for volunteers serves an essential purpose and reaches 
a basic need of people to be accepted and needed. This need is especially acute at a time when personal lives are in an extreme state of flux and uncertainty.

The only prerequisite for participation in the Center activities is to be a single adult person. The Solo Center is presently operating on monies from small fees charged, ranging from fifty cents for a drop-in fee to one dollar for attending a rap group with fees of from a dollar and a half to two dollars for most classes and seminars. Many of the classes are conducted by professional people who are paid a percentage of the fees and are, in essence, donating their time and expertise. To date, this source of income has paid the operating expenses of the Center but has provided no staff salaries. Search for an additional source of income is ongoing and is becoming imperative for survival.

There has been increasing confirmation of the validity of the services offered by the Solo Center from three highly visible and impactful sections of the community:

(1) There has been a steady rise in referrals to the Center from family service agencies and mental health clinics.

(2) The news media is showing increasing interest in interviewing Solo Center Staff for newspaper articles and radio/TV public interest series.

(3) Requests for Solo Center staff to speak to high school and community college classes on various aspects of the impact of divorce reflect a broadening interest in the problem and a real dearth of available literature.

This increasing interest reflects the rising incidence 
of divorce with its attendent problems. Although some of the figures relating to divorce are not clear, they are indicative of the dramatic spiral that has been occurring. In an article in the New York magazine it was stated that "National figures show that the divorce curve soared $82 \%$ between 1963 and 1972."

The problems rising from divorce are often traumatic. They can be overwhelmingly pervasive in their impact on a person's ability to cope. Dr. T.H. Holmes of the University of Washington conducted a study into the effects of a clustering of life event changes on a person's adaptability and reaction to stress. He recognized divorce and loss of a spouse by death as two of the most stress-producing events in an individual's life experience. But it is also a time when many other concomitant changes can add and build to a veritable congery of stress, i.e. change of residence, change in status, change in economic capability, change in role expectations -- the common thread is change. It is, therefore, not unexpectêd that both men and women going through the process of divorce often lose a sense of perspective and are unable to objectively assess the realities of their situation.

This time of crisis can be the fulcrum on which an individual can take charge and start reorganizing his life creatively. Emotional divorce and creative rebuilding are do-it-yourself projects, but interaction with other people 
can be considered a sine qua non factor in the process. Free discourse with others who can share similar experiences and dilemmas, as well as discuss possible solutions and alternatives, is one of the major tools needed to get the job underway.

". many arguments . . arise because certain words have contradictory meanings and each person believes his or her meaning is the only meaning. The picture of reality held by each is his own unique picture of reality -- a limited knowledge of that reality -and each is unaware that he or she has only a partial picture of reality."

The Solo Center is designed to help provide those tools and provide the milieu in which to practice new skills in communication, in problem-solving, in relating to others, in learning to feel comfortable living as a single person. Using the "powerful potential for action" latent in the relevant interaction between the members of a small group is not a new concept. Self-help groups, such as Synanon, weight-watchers, and groups for abusive parents, to name a few, recognize the ". . importance of common experience as the real basis of communication." 5 Making use of the potential in the group process and setting up opportunities to interact with other single people has been a major contribution in building the usefulness of the Solo Center. 
In a different setting and for a different purpose, but dealing with a similar population of persons involved in the process of divorce, the intervention planned by the IDCAP project is also based on the benefits accruing to individuals who participate in small group interaction. 


\section{IDCAP}

This project, titled "The Impact of Divorce on Children and Parents", was developed by the Project Director, Dr. Stanley N. Cohen. The research component has been funded by the LEAA funds administered by the Portland State University Division of Urban Affairs. The second phase of the study will be a demonstration project, which to the writer's knowledge has not yet received funding. A general description of the proposed work is given below:

The study focus is child custody. It has been recognized that the judges who must render the final decision on the custody of minor children involved in divorce action have very little, if any, objective information on which to base that decision. It also appears to be a fact that there is almost no available in-depth demographic and attitudinal information to draw from in developing an adequate and clear picture of what divorcing couples and their children really "look like." Tangential to these issues, the study is perceived as offering an opportunity to examine whether parenting styles and attempts to prepare children for the advent of a divorce effect their emotional and physical development prior to, during, and after a divorce.

The data will be collected from a random sample comprised of 125 first married couples with minor children 
filing for divorce in Clackamas County. The project developers plan to interview both divorcing parents. Cooperation of attorneys and school officials in gathering other needed data has been established.

The project objectives as noted in the proposal are:

a. A comprehensive descriptive analysis of the demographic and attitudinal characteristics of a random sample of first married divorcing couples with minor children;

b. A descriptive analysis of the factors considered by courts in determining custody in non-contested cases;

c. A descriptive analysis of those social and personal factors operating with a family that prompt intervention by courts in determining child custody;

d. An 18 month longitudinal study of the extent to which parenting styles developed by couples prior to, during and after divorce, effect the psycho/social development of their children.

With regard to these objectives, the major independent variables are whether the children were prepared for their parents' divorce and the "type" of parenting styles developed by the divorcing couple. The major intervening variables are social class and cultural attributes (income, occupational status, race/ethnicity, religious orientation.)

The dependent variable in the children's developmental adjustment is defined by:

1. their performance at school as assessed by the child's teacher;

2. their relationship at home as assessed by the 
custodial parent;

3. their relationship with the non-custodial parent (if any);

4. their health status as assessed by their parents and teacher; and

5. their peer group relations as assessed by their parents.

The kinds of data generated in this study will provide an accurate, previously unavailable descriptive picture of divorcing families, their ideas about post-divorce parental responsibilities, the extent of their satisfaction with custody, child support, visitation decisions and the kind of parenting styles that evolve among divorcing parents. Such information is considered an important factor that may be related to a child's readjustment to divorce in non-contested and contested cases. It is believed that such illustrative information is important with regard to:

1. Father/daughter awards

2. Award to mother when both parents work

3. Court not awarding custody to requesting parent

4. Frequency with which father is awarded custody

5. Award to working mother when father is unemployed

6. Frequency with which court intervenes in noncontested cases

7. Father awarded custody of pre-school aged children

8. Mother awarded custody of pre-school aged children when both parents work.

An assumption is made in this study that a cooperative parental style is healthy for children in divorced circumstances and has a direct effect on their development prior 
to, during and after divorce. For purposes of this study

a cooperative parental style is one of agreement to provide:

1. Their children support in their authority relationships at home, school, community;

2. Support to each other and use of similar discipline patterns when with their children,

3. The non-custodial parent opportunity to spend more time with the children; and

4. The custodial parent with support in the event unexpected problems involving the children arise.

In a like manner, a cooperative parental style is assumed to provide the children and parents opportunities to adapt to circumstances occasioned by the divorce such as :

1. An absent parent;

2. Remarriage of one or both parents;

3. Relocation;

4. Illness of parent.

It is also important to note that social economic circumstances may effect the parental style and coping behavior of divorcing parents as they relate to their children's needs and may, in fact, shape their responses to children.

Based on the information and assumptions presented above, the IDCAP project developers noted several hypotheses which can be generated and empirically examined. The following are examples:

1. Children whose parents have prepared them for divorce and have established a cooperative 
parental style will exhibit the best developmental adjustment of any group of children involved in divorce.

2. Children whose parents have prepared them for divorce will exhibit a better developmental adjustment than children not prepared for divorce.

3. The social economic circumstances of divorcing parents is inversely related to the development of cooperative parental styles.

4. The children of parents who have established a cooperative parental style will exhibit a better developmental adjustment than children whose parents did not establish a cooperative parental style.

Details of the information sought from the parents are indicated by the questionnaire. Data about school matters will be obtained from the schools. (See Appendix A for copy of the quesionnaire.)

The second phase of the IDCAP study will be a demonstration project. One-half of the sample population, or approximately 60 couples, will be assigned to participate in a planned intervention program, and one-half will serve as a control group.

It is the writer's understanding that the objectives of the intervention are as follows:

1. To assist the participants in separating the marital relationship from the parenting relationship;

2. To explore ways by which the parents can develop a more cooperative parenting style.

3. To refine parental communication skills for use in explaining the divorce to their children and in dealing with issues that arise during and after the divorce. 
The intervention program will involve a series of three discussion periods conducted at weekly intervals in a small group setting with a trained leader. Each small group will be made up of not more than five couples. (Please note that this figure was arbitrarily set by the writer.) Since involvement of both parents will be required, there will be ten parents in each group, plus a leader. The discussions will be focused on the following issues:

1. Their roles as separated parents, exploring the kinds of issues they have to deal with;

2. Understanding that their marital problems have nothing to do with their relationship problems;

3. What custody means; what child support means; what visitation means -- in the context of working these things out;

4. The consequences to themselves and to their children if they don't develop a real understanding of the issues and problems involved and a realistic view of the future.

As a further aid in claxifying the issues involved, Dr. Cohen plans to develop a film which would be designed to stimulate and raise awareness. This film will be presented at the first group meeting. It will delineate some of the more critical issues that parents and children have to contend with in a divorce and how parents deal with them.

In addition, it is contemplated that three more discussion group meetings could be held by the parents on a voluntary basis with possibilities that parents could extend discussion groups on their own, if they should wish. 


\section{METHODOLOGY}

The questionnaire used in this study was developed in collaboration with Dr. Stanley Cohen, Project Director, and Nolan Jones, Research Assistant of a longitudinal project, titled "The Impact of Divorce on Children and Parents." Following is a description of the methods used by the writer in conducting a pretest of the questionnaire at the solo Center, which was the major purpose of this study.

This is a descriptive study of a selected group of twenty divorced or separated individuals with minor children, who were currently using the solo Center as a resource. Fourteen women and six men were interviewed. The research instrument included a total of fifty-five questions. Twentythree questions were designed to gather demographic data. Thirty-two questions probed attitudes and perceptions relating to the divorce process.

The writer remained aware of the two-fold purpose of the interviews:

1. First, to obtain information on the efficacy of the questionnaire in generating the data desired, remaining cognizant of questions which were not clear or were not easily understood and easily answered.

2. To obtain factual information, plus subjective impressions and reports of the experiences and reactions which developed before, during and after the divorce; to explore evidence of agreement or disagreement between the divorcing couple in reaching decisions on four major issues: 
a. Decision to divorce

b. Child custody

c. Child support

d. Visitation arrangements.

The methodology used to accomplish the above stated purpose was as follows:

Each subject was handed a questionnaire and asked to check at least one answer, or more if applicable, for every question. When the questionnaire had been completed, the writer rapidly reviewed the twenty-three demographic questions, to verify that every one had been answered.

Next, the writer approached each of the remaining thirty-two questions, using what has been described as the phenomenological method. Macleod describes the phenomenological method as applied to psychology as

- . the systematic attempt to observe and describe in all its essential characteristics the world of phenomena as it is presented to us. It involves the adoption of what might be called an attitude of disciplined naivete. The phenomenological question is simply. "What is there?" In a sense, every psychologist is a phenomenologist and no psychologist achieves the ideal.6

The second portion of the interview was taped. An attempt was made to maintain an attitude of "disciplined naivete" in order to allow spontaneous and subjective responses that were clearly the interviewee's own. Efforts were made not to lead or interject comments. Probing questions in a form such as "Can you tell me a little more 
about that?" were used when the writer felt it was necessary. The efforts of the writer in this method were only partially successful.

The subjects were informed of the dual purpose of the interview, i.e., to pretest the questionnaire for the larger research project which was being planned by the IDCAP team; and to gather data to be used in writing a paper in order to complete the requirements for a Master's Degree in Social Work at Portland State University. A typed memorandum giving the background of the research project in brief and detailing the mechanics of the process of the interview was shown to the subject at the beginning of the interview. (See Appendix $B$ for example of memorandum.)

There was no attempt made to collect a random sample. The writer wishes to emphasize that the data collected is of interest only in a descriptive sense, and that no attempt will be made to draw conclusions from the data generated. Except in two instances, only one of the divorced spouses was interviewed. The data collected was inevitably biased, and in some instances, highly emotionally charged. There was no attempt made to control the sample for sex, age, length of marriage, or lapse of time since divorce.

The sample was collected and interviews conducted as time and circumstances of both the writer and available Solo Center participants allowed. 
Table I, which follows, describes the interviewed subjects by age and duration of marriage:

\section{TABLE I}

SUBJECTS INTERVIEWED

\begin{tabular}{|c|c|c|c|c|c|c|c|c|c|}
\hline $\begin{array}{l}\text { Age at } \\
\text { Divorce }\end{array}$ & Tatal & $\begin{array}{r}\text { Male } \\
5-9\end{array}$ & $\begin{array}{l}\text { DURAT } \\
\text {-Fem. } \\
\text { yr. }\end{array}$ & $\begin{array}{l}\text { ION } \\
\text { Male } \\
\text { I0- }\end{array}$ & $\begin{array}{l}\mathrm{F} \text { MA } \\
\text { Fem. } \\
4 \mathrm{yr} .\end{array}$ & $\begin{array}{l}\text { RIAGE } \\
\text { Male-1 } \\
15-19\end{array}$ & $\begin{array}{l}\text { Fem } \\
\text { yr. }\end{array}$ & $\begin{array}{l}\text { Male } \\
20+\end{array}$ & em \\
\hline $26-28$ & 5 & 1 & 4 & 0 & 0 & 0 & 0 & 0 & 0 \\
\hline $29-31$ & 3 & 1 & 1 & 0 & 1 & 0 & 0 & 0 & 0 \\
\hline $32-34$ & 1 & 0 & 1 & 0 & 0 & 0 & 0 & 0 & 0 \\
\hline $35-37$ & 3 & 0 & 0 & 2 & 0 & 0 & 1 & 0 & 0 \\
\hline $38-40$ & 3 & 1 & 0 & 0 & 1 & 0 & 1 & 0 & 0 \\
\hline $41-43$ & 1 & 0 & 0 & 0 & 0 & 0 & 0 & 0 & 1 \\
\hline $44-46$ & 0 & 0 & 0 & 0 & 0 & 0 & 0 & 0 & 0 \\
\hline $47-49$ & 2 & 0 & 0 & 0 & 1 & 0 & 0 & 0 & 1 \\
\hline $50-52$ & 1 & 0 & 0 & 0 & 0 & 0 & 0 & 0 & 1 \\
\hline $53-55$ & 1 & 0 & 0 & 0 & 0 & 1 & 0 & 0 & 0 \\
\hline TOTALS & 20 & 3 & 6 & 2 & 3 & 1 & 2 & 0 & 3 \\
\hline
\end{tabular}


Table 2, which follows, described the interviewed subjects by sex and length of time lapse since divorce or separation:

TABLE 2

SUBJECTS INTERVIENED

\begin{tabular}{lcccc}
\hline \multirow{2}{*}{ Sex } & \multirow{4}{*}{ Total } & \multicolumn{4}{c}{ Time lapse since divorce or separation } \\
& Under 1 yr. & $1-2$ yr. & $3-4 \mathrm{yr}$. \\
\hline \multirow{2}{*}{ Wen } & 6 & 2 & 2 & 2 \\
\multirow{2}{*}{ Tomen } & 14 & 5 & 6 & 3 \\
\cline { 2 - 5 } & 20 & 7 & 8 & 5
\end{tabular}


Table 3, which follows, describes the interviewed subjects by the level of agreement or disagreement reached with their spouse indicated in four areas: (1) decision to divorce; (2) child custody; (3) child support; (4) visitation.

TABLE 3

SUBJECTS INTERVIEWED

\begin{tabular}{|c|c|c|c|c|c|}
\hline \multicolumn{4}{|c|}{$+A C$} & \multicolumn{2}{|c|}{$-D C$} \\
\hline & & $\mathrm{V}$ & $-D V$ & $+A V$ & $-D V$ \\
\hline \multirow[t]{2}{*}{$+A D$} & & 6 & 0 & 1 & 0 \\
\hline & $-\mathrm{DCS}$ & 0 & 0 & 0 & 0 \\
\hline \multirow{2}{*}{$-D D$} & $+\mathrm{ACS}$ & 4 & 0 & 1 & 2 \\
\hline & $-D C S$ & 2 & 1 & 0 & 3 \\
\hline TOTA & & 12 & 1 & 2 & 5 \\
\hline
\end{tabular}

$A C=$ Agree Custody

$D C=$ Disagree Custody

$A V=A g r e e$ Visitation

DV = Disagree Visitation
ACS = Agree Child Support DCS $=$ Disagree $C$. Support $A D=$ Agree Divorce DD " = Disagree Divorce 
Table 4, which follows, describes the interviewed subjects by level of agreement or disagreement reached with their spouses in four areas: (1) decision to divorce; (2) child custody; (3) child support; (4) visitation. The level of agreement or disagreement is described in relation to sex and monthly income.

\section{TABLE 4}

SUBJECTS INTERVIEWED

\begin{tabular}{|c|c|c|c|c|c|c|c|}
\hline \multirow[t]{2}{*}{$\begin{array}{l}\text { Monthly } \\
\text { Income }\end{array}$} & \multicolumn{3}{|c|}{$\begin{array}{l}\text { Three or more } \\
\text { "minus" } \\
\text { Categories }\end{array}$} & \multicolumn{2}{|c|}{$\begin{array}{l}\text { Two "plus" \& } \\
\text { two "minus" } \\
\text { Categories }\end{array}$} & \multicolumn{2}{|c|}{$\begin{array}{l}\text { Three or } \\
\text { more "plus" } \\
\text { Categories }\end{array}$} \\
\hline & Total & Men & Fem. & Men. & Fem. & Men. & Fem. \\
\hline Less $\$ 200$ & 0 & 0 & 0 & 0 & 0 & 0 & 0 \\
\hline $200-399$ & 5 & 1 & 2 & 0 & 0 & 0 & 2 \\
\hline $400-599$ & 3 & 0 & 2 & 0 & 0 & 0 & 1 \\
\hline $600-799$ & 3 & 0 & 1 & 0 & 1 & 0 & 1 \\
\hline $800-999$ & 2 & 0 & 0 & 0 & 1 & 0 & 1 \\
\hline $1000-1199$ & 2 & 0 & 0 & 0 & 1 & 0 & 1 \\
\hline $1200-1399$ & 3 & 0 & 0 & 0 & 0 & 3 & 0 \\
\hline $1400-1599$ & 0 & 0 & 0 & 0 & 0 & 0 & 0 \\
\hline $1600-1799$ & 0 & 0 & 0 & 0 & 0 & 0 & 0 \\
\hline $1800+$ & 2 & 0 & 0 & 0 & 0 & 1 & 1 \\
\hline $\begin{array}{l}\text { TOTALS } \\
\text { * "minus" } \\
\text { "plus" }\end{array}$ & $\begin{aligned} & 20 \\
= & d i \\
= & a g\end{aligned}$ & 1 & 5 & $I$ & 2 & 4 & 7 \\
\hline
\end{tabular}




\section{GENERAI OBSERVATIONS ON SUBJECTS INTERVIEWED}

As has been mentioned, the subjects were not controlled for variables on age, duration of marriage, or time lapse since divorce. All subjects had been married one time only. The distribution on the above variables is noted below: AGE:

Seventy-five percent of the sample were forty years old or younger, with twenty-five percent of these in the 2628 age category. Average age - 36.7 years Median age - 36.0 years Range $\quad-26-55$ years

DURATION OF MARRIAGE:

Forty-five percent of the sample had been married between five and nine years; twenty-five percent fell in the ten to fourteen year category; fifteen percent in the fifteen to nineteen year category; and fifteen percent had been married twenty years or more. Average duration of marriage -12.5 years Median duration of marriage -11.0 years Range 5 - 27 years

TIME IAPSE SINCE DIVORCE:

Under one year

$-35 \%$

One - two years - $40 \%$

Three - four years 25\% 
The twenty divorced or divorcing individuals interviewed at the Solo Center offered examples along a full continuum from very "role-controlled" individuals to some moving toward a "role free" viewpoint of life style and behavior patterns.

Some questions on significant issues of special interest were raised in the writer's mind. Some of these questions and the impressions received during the course of the interviews follow:

1. What was the general impression conveyed by attorneys to clients on the decision-making process? Examples of attorneys attitudes were given by three fathers who had sought information from their attorney regarding gaining custody of their children. One reported that he was told there was no point in trying to get custody. The divorce was being obtained in a small, conservative town and "there's just no point in fighting." Another father was told, "Forget it. What makes you think you'd be any better than your wife?" A third father said that his attorney wouldn't even discuss it with him.

One mother was told by her attorney that if she were to go to a marriage counselor, she would get a divorce for sure. Another woman expressed her chagrin as she described how she and her spouse of many years had reached very amicable arrangements on the details of property settlement, which the attorneys proceeded to argue against. Her impression was that the attorneys had a vested interest in 
"winning."

2. What assumptions seemed to be operating in the decision making process, relating to child custody, child support, and visitation? There appeared to be a consistent feeling that the mother was probably the best qualified and most capable of having custody of the children. Those mothers who expressed some wish to have more freedom from the responsibility did not appear to hold this as a realistic expectation. There were comments such as "With his work, he wouldn't be able to manage;" "He's just not interested in being tied down." Within this very small sample, there appeared to be very little thought or consideration of any type of shared custody.

In regard to child support and visitation, there was a frequently heard connection between these two issues with visitation sometimes used as a threat to force payment of support, and sometimes seen as something that was a "right" because it had been paid for by child support.

3. What were the general effects of the level of agreement/disagreement between the marital partners on the decision-making process? There was no pattern that would indicate any obvious tie between the overall level of agreement and the general degree of conflict between the spouses.

\section{CUSTODY}

Of the twenty subjects interviewed, eighteen reported that the mother had custody of the children; one subject 
(a man) reported a split custody arrangement; and one subject reported that the mother had received custody, but one of the children, a teen-age boy, had moved in with the father due to conflict with the mother.

Following is a brief description of one subject's report of a split custody arrangement. The mother was awarded custody of the eight and fourteen old daughters; the father was awarded custody of the thirteen year old son. However, in actual practice they shared custody of all three children.

He explained what appeared to the writer to be a unique arrangement. By design, the parents live within a few blocks of each other. The three children alternate between the two homes on a consistent schedule -- all three shifting en toto three times per week. This pattern was originally established to fit with the parents' work schedules. The children ride the same school bus and attend the same school from both homes.

Some of the factors contributing to the success of this arrangement, which has been functioning for over a year, appear to be:

1. The parents ability and willingness to perceive their parenting relationship as separate from their former marital relationship.

2. The age of the children, plus their adaptability to the arrangement. An added assist was their friends quick accommodation and adjustment to the schedule.

3. Above-average income. 
4. Similarity of parenting style and expectations.

All other things being equal, this method of sharing the responsibilities of child care in its total dimension could be one answer to the point made by William Goodes

Parents become physically and psychically weary in their constant attempts to socialize their children, who are their superiors in energy output, speed of energy recovery and 7 cleverness at finding escapes from pressure.

The general impressions received by the writer reinforce the IDCAP team's special interest in question \#48 on the questionnaire:

During the divorce proceedings, do you think it would be helpful to have someone sit down with you and your spouse in order to work out a parenting relationship that would be the most beneficial for your children?

There was a strong positive response to this question with fifteen subjects marking "yes" answers, and five subjects marking "no". It would appear that the subjects in this sample would welcome some guidance and help through a difficult transitional period when many important issues must be decided. 


\section{STATISTICS ON DIVORCE}

There is a very real and growing need for research such as being demonstrated in the IDCAP project.

Divorce statistics, as they are compiled, do not approach a degree of accuracy which could provide a profile of divorce and marriage, let alone provide a matrix for completing a picture. In conversation with a person in the research and statistical section at the Bureau of Vital Statistics for the State of Oregon, the writer received figures of 5.711 divorces in Oregon in 1960 and 13.583 divorces in Oregon in 1974. This reflects an increase of $138 \%$ in a fourteen year period: This is a startling enough rise to provide "solid data" for those who foretell the doom of marriage as an institution in our society. But additional information was offered to the effect that the research staff had reservations about their data in a number of areas:

1. They had serious doubts about the completeness of their data. They had just received notices of an additional one hundred and fifty divorces granted in Oregon in 1974. These records had been "set to one side" by a judge.

2. Their records indicated no accurate data on remarriage or "re-divorce."

3. Current records (1973) indicate 4,932 minor children were involved in 12,946 marriage dissolutions. The writer was advised that these figures may not include all of the minor children affected. Children from a former marriage by one or both spouses, for example, may not be listed in the records. 
Adrian Bradbrook noted in an is sue of the Journal of Family Law that "75\% of all divorcees remarry within five years, and that $18 \%$ of all marriages in the United States are remarriages for one or both spouses..." ${ }^{8}$ This information may or may not be reflected in available records. Reverend Gordon Dickey in his report, Divorced Catholics:

An Imperative for Social Ministry, commented:

"Research literature on divorce in general, and on religion and divorce in particular, is conspicuous by its absence ... Most authors admit to a knowledge gap which handicaps even statistical research on religion and divorce." 9 


\section{BACKGROUND}

The paucity of complete and accurate data contributes to the ambiguity and complexity of the issues and problems raised by divorce and demands thoughtful attention. The range of variables operating in a family system have led to a widespread dependence on assumptions and generalizations in assessing the impact of divorce. Some of the more important variables are:

1. Socioeconomic factors, including individual history and level of employment, as well as the general level of employment and prosperity in the society;

2. Religious orientation;

3. Strength or weakness of kinship ties and support network;

4. Number and ages of children;

5. Level of agreement and/or disagreement between the marital partners on basic issues:
a. Money management
b. Iife style
c. Parenting style
d. Long-term goals

Many of the attitudes toward divorce reflected in our social philosophy are buried in assumptions and generalizations which carry a strong negative connotation. The label "broken home" is commonly seen in the literature on divorce. The descriptive term "broken home" is often seen as leading to juvenile delinquency, school dropout, alcoholism, depres- 
sion and suicide. This perjorative attitude is extended to the further assumption that the disorganization and upheaval which are often clearly apparent in a family during the divorce process is likely to continue for an indefinite period with concomitant damage to the children.

Any major change within the family grouping can create a period of disruption and tension, affecting each member and especially the children. New family members enter the scene through birth. Members leave for a job or school, through marriage, illness and death. For whatever reason, the existing balance is altered, and the remaining members must relate to each other in new ways. Changes such as these touch every family at different periods in its life and are universally accepted and recognized. Our social philosophy acknowledges these as inevitable, passes no judgement, affixes no stigma of failure and expects reorganization to be accomplished within a reasonable period of time. All of the protagonists living out these dramas know their parts and what is expected of them. This is not true of divorcing parents.

As succinctly stated by Jane $\mathrm{K}$. Burgess in an article appearing in The Family Coordinator with the title "The Single-Parent Family: A Social and Sociological Problem:"

A parent who is alone as a result of divorce, separation, or death has many problems that do not arise in a twoparent family. Changes take place in

the sexual area, in parent-child relations 
where one parent now assumes the principal responsibility, and in the economic structure of the family. Probably the most difficult problem facing the single parent comes from the attitudes and behavior of society which isolates to a degree the single spouse from the mainstream of a former socioeconomic way of life. 10

The widely used adjective "stable" when referring to the two-parent family delivers a strong clue to our societal judgement on the issue. Often the advice received by divorcing parents with minor children carries a covert message that they have failed at their most important task -- that of providing a stable, loving home environment for their children. This message can provide fertile ground for extending the marital battlelines into the parenting relationship with each parent anxious to relieve his own feelings of failure.

The writer has developed an on-going interest in the power of language and its influence on behavior, through the continual internal coversation which preoccupies us and through our interpersonal conversations. The following quote from Wendell Johnson carries significant meaning in relation to this study:

- For I am convinced, through my own studies and the studies of others, that language fashions and limits our thinking far more than our thinking determines our use of language ... This language of the ancients is our folk language, the common everyday language in which you and I carry on our everyday chatting with our friends and 
neighbors. Made in a world that had to be seen as static to be bearable, it is a static language, which we try to make do in a process reality. It is full of the adoration of certainty. It is so constructed that our feelings, even the ancient fears and suspicions, can sound so much like facts that we often do not notice they are not. It is a categorical language with devices for lumping and labeling and generalizing (emphasis is made by the writer) that seem to give us, as they did the ancients, an illusion of understanding. It is a self-andothers language, a language of one-way relationships, a language of separation from others, rather than of the community of man. It is a language born out of very impressive ignorance. II

The writer suggests that although society's judgemental

attitudes toward divorce per se are lessening, stereotypic

language and thinking serve to maintain strong blaming reactions toward the divorcing parents. In an article, "Legislative Reform of Child Custody Adjudication" by

Phoebe C. Ellsworth and Robert J. Levy it is stated:

Almost all of the studies that deal with the effects of different childhood living arrangements on the development and later adjustment are correlational. The statement that "correlation does not imply causation" has become a truism for social science methodology, and yet for several reasons it must be reemphasized in relation to these studies. First of all, both psychological theories and American culture more generally tend to perpetuate stereotypes about the causal nature of certain childhood experiences: "Every child needs a mother," "Every little boy needs a father," "Divorce is inevitably a traumatic experience for a child," etc. These stereotypes often result in insufficient attention to alternative hypotheses in interpreting correlational data. 
Ellsworth and Levy continue:

The measurement problem alone would be serious, but coupled with the extremely strong prejudices that adequate social and personal development require an intact home, it becomes dangerous. On the antecedent side . . it can lead to a lack of attention to other factors of possible relevance. On the consequent side, the same risk is present; in addition, the consequences may be misrepresented or exaggerated . . . It is impossible, of course, to separate out the effect of predivorce conflict and the divorce itself in a study that lacks pretesting. In relation to this question, however, Goode (1955) found that the majority of mothers reported their children to be as well behaved or, better behaved after the divorce than before. 13

It has been suggested that:

Failure to perceive the good adjustment both of children and spouses in many broken homes may stem from a concentration upon the tensions and adjustments which occur at the time of the break. After a period of adjustment, a new equilibrium is established, complicated perhaps by the necessity for each family member to play new and less clearly defined roles, but largely free of the unbearable conflicts of the
previous unhappy marriage. 14

Family "stability" and the structure of marriage, as we experience it, are under heavy pressure from an accelerating rate of change. The institution of marriage has served a vital function in society and has provided the environment to nurture the children and support the workers our complex technological society has required. Elizabeth Janeway, in "Man's World, Woman's Place, comments that: 
- how much is done for children by parents alone depends very much on the society in which the family exists, on the social and economic demands that society makes on the parents in other ways, and on the help it offers them in bringing up their children and instructing them in the mores of the community. 15

\section{FORCES OF CHANGE}

Today there are vital and far-reaching changes impacting on our attitudes and on our behavior, influencing broad facets of our environment, our interpersonal relationships, and our intrapersonal perceptions. Some of the forces precipitating these changes are:

1. Socioeconomic trends over the past thirty to forty years have been shifting emphasis from a survival-oriented society to one of surplus. The "have-nots" in our society have been demanding a greater share in the economic benefits. Interest in developing the potential of the individual and seeking opportunities for greater self-fulfillment and personal growth has been increasing. The proliferating human growth movement is a reflection of this change. 2. The lengthening period of active "middle years". opens up new options to many and can conceivably affect family life patterns and the incidence of divorce.

A few generations ago, the curve of the average individual's life span followed a skewed pattern with a long gradual slope to the top, a relatively limited plateau, then 
a sharp descent. For an increasing number of people, this configuration is changing to a more symmetrical pattern with a much broader plateau at the top. As Anne Simon aptly described in her book, The New Years, A New Middle Age:

For the first time in history and for the first time in his life, man (and woman) of middle age can comprehend the great sweep of the life span as it now stands revealed. He can order his life to suit the new facts about getting older which it has brought to light, seize its options, pioneer. 16

3. The world concern over the necessity for population control continues. Family size limitation and the thoughtful decision by some individuals not to reproduce have had influence. This changing perception contributes to the need for a new look at family life and family purpose.

4. The increase in sheer numbers of people divorcing brings a greater percentage of individuals into direct confrontation with the problems generated and the adjustments needed.

5. One of the greatest forces for change has come from the women's movement and the equal rights legislation, both of which are demanding a reassessment of role expectations and function in society for both men and women.

THE WOMEN'S MOVEMENT AND CHANGING ROLES

". . the future shock we are living with is a force that tells us we must change the old roles and the old image of women." Women are responding to that force in what 
appears to be a growing stream and are embracing new concepts of themselves which could lead to changes in our whole social structure. It would appear useful to utilize a more holistic perspective of what is going on in our society in order to approach with some understanding the vigor of the changes. Women's move to reevaluate their roles and the limitations structured into their traditional role is not occuring in a vacuum.

The pace of change sparked into action by the activities of women's "lib" appears to be affecting all areas of social interaction. This proliferating evolution of thought: and action has begun to draw forth significant responses from her fellow protagonist. Men are being forced to look at their own roles, as the tension grows in this dramatic conflict. The writer submits that there is room for two on center stage and that the actual sharing of the top billing could lead to a synthesis and eventually a move toward a synergic society. Synergy is a brilliant concept of anthropologist Ruth Benedict. For purposes of this paper, synergy is defined as being evident in ". . social orders in which the individual by the same act and at the same time serves his own advantage and that of the group." Synergy is an interesting concept which could be used as a point of reference in examining the roles of men and women and their relationships with their children.

We are living in the midst of a transitional period. 
This period of change could have a greater impact on our society than the Industrial Revolution, but " . . significant changes in a society's system of social policies are not likely to occur without thorough changes in its dominant beliefs, values and ideologies, (and institutions)." 19 The dominant value and belief systems of our society, including the dominance of the male's position, were established early in man's history. Man retained power and control for himself across all of the various orders of social institutions, especially the highly important kinship order, the economic order (which the writer sees as the basic point of control in the twentieth century society), as well as political, military and religious orders. "In Western society, as elsewhere, sex acts as the master status, channeling one into particular roles and determining the quality of one's interaction with others." Within the structure of the family institution, a self-image starts to form as a reflection of the approval and criticism of significant others, who in turn are reflecting their interpretation of the norms of behavior and expectations to which they were shaped.

Roles, useful in facilitating social interaction at many levels and providing a degree of stability and continuity, also serve to maintain and reinforce positions of power and dominance in men and the complementary position of submission in women. Women have been restricted to two major 
roles acceptable in society -- that of wife and mother. "There are ample grounds for assuming that women find their position in society to be more frustrating and less rewarding than men and that this may be a relatively recent development." 21 It takes an abundance of conscious, long-range and often discouraging effort to make changes in the deeply engrained programming which started functioning when we were born. Tremendous effort and energy are involved in making a major life style change and deliberately moving out of the role society has set up for you. The role of an individual, autonomous woman has very few guidelines and very little status (unless she has a source of economic power.) There is a "need to establish new norms and get rid of the old ones that don't fit today's world," and to deal with "the tendency we all have to imagine that problems of how we deal with our personal lives are merely personal .... By doing this, we reduce a social problem to a personal problem ... and thus we make it insoluble because we've isolated it from its context."

"Social structure, not personality, is what must be understood if we want to know why divorce is rampant and why families are not happy." 23

These forces for change come into contact with great resistance. Societal change is a slow, incremental process. The title of Elizabeth Janeway's book, Mian's World, Woman's Place still carries a poignant message. Marriage is still 
the only generally acceptable framework within which men and women are expected to build satisfying lives. Even though there has been some slight easing of these expectations in the past few years, remaining single, or becoming single again through divorce, still bears the onus of personal failure.

Howard B. Lyman, Ph.D. made a comment in his book, Single Again, "If society made it more acceptable for people to remain single, life might be happier for many and innumerable unhappy marriages might not have been committed." 24 The Solo Center, now in its second year of operation, is designed to offset this discriminatory pressure by offering singles an opportunity to share ideas, problems, new experiences, and learn of alternatives and options. In observing and listening to both women and men in various groups at the Center, it appeared to the writer that the closely interwoven issues of custody, child support, and visitation rights were ongoing battlefields and were fraught with hostility, resentment and anger. This was evident in the statements of many divorced individuals, even though the settlement of their divorce had been finalized a year or more previously. As Mel Krantzler remarked in his book Creative Divorce:

Divorce courts, forcing both parties into a system associated with criminals and lawbreakers, reinforce the notion that one party is innocent and the other guilty. Although the adoption by some states of "no fault" divorce has taken the element 
of blame out of financial settlements,

it has not removed it from the divorce proceedings. Blame has simple been shifted to the area of child custody and visitation rights. What often happens as a result of this shift in battleground is that the husband and wife, frustrated by law from seeking revenge through economic means, take out hostilities through their children -- who are the ultimate casualities of bitter custody fights.25 
CONCLUSION

This study has made no attempt to draw conclusions from the data. The main thrust of the paper is the pretest of the questionnaire for the IDCAP project (Impact of Divorce on Children and Parents.)

The responses to the questions by the interviewees were critically examined and changes in the questionnaire introduced and tested as the study evolved. The questionnaire, as shown in Appendix $A$, has been changed slightly, introducing a group of questions which probe the religious orientation and involvement of the family. Otherwise, it is substantially the questionnaire that will be used by the IDCAP project in Clackamas County, which is tentatively planned to be operational in June, 1975.

The writer is convinced that the orientation and projected intervention, as planned by the developers of IDCAP, deserve the critical attention of the social work profession as well as educators, lawyers, judges and all those who deal with families and children in our society. Informal estimates by knowledgeable persons in many different fields of interest range up to 850,000 single parent families in Oregon by 1975.

This growing population needs more than cursory attention and haphazard support. It needs innovative. thinking based on a more positive, future-oriented program of preventive measures. The controlled study being 
effected by the IDCAP staff, which involves intervention at the time of filing for divorce, as well as a series of follow-ups over the ensuing eighteen months, appears to be a realistic approach. This research is designed to produce hard data, which is essential for constructive, consequential planning.

Paul Bohannan in Divorce and After states:

Another confusion in our present attitudes toward divorce and remarriage comes from our refusal to treat the conception and production of a child as an unbreakable tie between the parents, regardless of

The disparity between the actual facts and many of our expectations and assumptions serves to obfuscate the objective and clear understanding that is needed in planning and creating more effective results. Bohannan also remarks:
Americans badly need some kind of com- munity campaign for understanding the problems that regaining emotional autonomy involves; for creating for divorced persons a positive role with a moral dimension, for creating a morality about the rights and ob- ligations of divorced coparents that depends less fully on the courts for its sanction and therefore is more likely to work. 27

Expansion of the concept of divorce counseling, as a separate and distinct service, is one approach to the problem. The Director and Staff of the Solo Center have been in contact and correspondence with the National Council on Family Relations, Task Force on Divorce and 
Reform. In their 1974 report are the following comments:

Divorce counseling is a new concept just beginning to take shape. It focuses on the adjustment process with the goals of an amicable divorce, personal growth and the development of a fulfilling lifestyle as an individual. 28

The writer would also suggest that another goal of divorce counseling is in developing an amicable and cooperative parenting style in the interest of reducing the trauma of divorce for children. The results of accomplishing such goals, relating to a positive adjustment to the process of divorce and its aftermath, could be a powerful force in Community Mental Health.

David R. Mace, a professor of sociology and a founder of the American Association of Marriage and Family Counselors wrote an article, "In Defense of the Nuclear Family" which appears in the May/June, 1975 issue of The Humanist. He affirms the following:

What we need to change is not the way in which people are grouped together in social systems, but the manner in which they
interact with each other as persons. 


\section{A SELECTED BIBLIOGRAPHY}

Abeel, Erica, "Divorce Fever: Is It an Epidemic?" New York, Vol. 7, No. 44, November 4, 1974, New York, p.46

Avery, Curtis E., and Lester A. Kirkendall. The Oregon Developmental Center Project in Family Iife Education C.E. Brown Trust., Portland, Oregon , 1955.

Bateman, Dorothy E., Michael A. Comte, et.al., Changing the Custody of Children Whose Parents Have Been Divorced: A General view of the Process, Portland State University, 1970 .

Bohannan, Paul, Ed. Divorce and After, Doubleday \& Co., Inc., New York, 1971.

Bosco, Antoinette. Marriage Encounter, The Rediscovery of Love, Abbey Press, Indiana, 1973.

Bradbrook, Adrian. "The Relevance of Psychological and Psychiatric Studies to the Future Development of the Iaws Governing the Settlement of Inter-Parental Child Custody Disputes," Journal of Family Law, Vol. 11. pp 557-587.

Brooks, William D. Speech Communication, William C. Brown Co., Iowa, 1971.

Burgess, Jane K. "The Single-Parent Family: A Social and Sociological Problem, " The Family Coordinator, Vol. 19. No.1 (April, 1970), pp 228-236.

Champagne, Marian. Facing Life Alone, Award Books, New York, 1969.

Chapman, A.H.. M.D. The Games Children Play, G.P. Putnam Sons, New York, I97I.

Cohen, Stanley N., Ph.D., Project Director. "The Impact of Divorce on Parents and Children" An unpublished report of a research and demonstration project in Clackamas County.

Coughlin, Bernard J. "The Rights of Children," Child Welfare, Vol 47, No. 3, March, 1968, pp 133 - 142.

Despert, J. Louise, M.D. Children of Divorce, Doubleday \& Co. New York, 1953. 
DeVito, Joseph A. Communication Concepts and Processes, Prentice-Hall, Inc., New Jersey, 1971.

Dickey, Rev. Gordon. Divorced Catholics: An Imperative for Social Ministry, November 1, 1974.

Eckhardt, K.W. "Deviance, Visibility and Legal Action: The Duty to Support," Social Problerns, VoI 15, No 4, 1968, pp. $470-477$.

Elkin, Meyer. "Short-Contact Counseling in a Conciliation Court," Social Caseworik, Vol. 43, No 4, April, 1962, pp. $184-190$.

Ellsworth, Phoebe C. and Robert J. Levy. "Legislative Reform of Child Custody Adjudication" Law and Society Review 1969, Vol. 4, pp 168-233.

Fisher, Esther 0 . Divorce, The New Freedom, Harper and Row, New York, 1974.

Gil, David G. Unravelling Social Policy: Theories, Analysis and Political Action Towards Social Equality, (Mass. 1973)

Glasser, Paul and Elizabeth Navare. "Structural Problems of the One-Parent Family," Behavioral Science for Social Workers Edited by Edwin J. Thomas, New York, The Free Press, 1967, pp 145 - 155.

Glidewell, John C. "On Love - Sought and Offered" Choice Points, Essays on the Emotional Problems of Living with People, The MIT Press, Mass. 1970, pp $104-136$.

Goode, William J. Women in Divorce, The Free Press, New York, 1956 (1965)

Gorney, Rodney, M.D. The Human Agenda, New York, 1968.

Gove, Walter R. "Adult Sex Roles and Mental Illness," American Journal of Sociology, Vol. 78, No 4, January 1973.

Hansen, Robert W (I.I.B.) "The Role and Rights of Children in Divorce Actions," Journal of Family Law, Vol 6, No 1. Spring, 1966, pp 1-14.

Hansen, Robert W. and Sidney J. Goldberg. "Casework in a Family Court," Social Casework, Vol 48, No 7, July, 1967, pp 416 - 421 . 
Haussamen, Florence and Mary Anne Guitar. The Divorce Kandbook, G.P. Putnam Sons, New York, I960.

Holmstrom, Lynda I. The Two Career Family, Schenkman Pub. Co, Camb. Mass, 1972 .

Hunt, Morton M. The Woxld of the Formerly Married, McGraw Hill Book Co, New York, 1966 .

Janeway, Elizabeth, quoted in the "Annual Report Edition. 1973 Mental Health Association of Oregon Newsletter, Portland Oregon, October 1973.

Janeway, Elizabeth, Nan's World, Women's Place, A Study in Social Mythology, William Morrow and Company Inc., New York, 1971.

Jaqua, Dr. Ernest J., Chairman, et al, City Club study, "Divorce and Children of Divorce," Portland City Club Bulletin, Vol 30, No 6, June 17, 1948, Portland Oregon.

Johnson, Wendell and Dorothy Moeller, Iiving with Change, The Semantics of Coping, Harper and Row Inc., New York, 1972 .

Kramer, Rita. "The Psychological Parent is the Real Parent," The New York Times Magazine, October 7, 1973/Section $6, \mathrm{pp} 70-73$.

Krantzler, Mel. Creative Divorce, M. Evans \& Co. New York, 1973.

Iichtenberger, James P. Divorce, A Study in Social Causation, AMS Press, New York, 1968.

Iodge, Thomas I. "Modification of Divorce Decrees with Respect to the Custody of Minor Children -- Oregon;" Willamette Law Journal, Vol. 2 No 2, 1962, pp 216-226.

Iyman, Howard B., Ph.D. Single Again, David McKay Co, Inc., New York, i971.

Mace, David R. "In Defense of Nuclear Family," The Humanist, Vol. XXV, No. 3, May/June, 1975, pp $27-\overline{29 .}$

Macleod, Robert B. "The Phenomenological Approach to Social Psychology," in Penato Taquire and Iuigi Petrullo. Person, Perception and Interpersonal Behavior, Palo Alto, Stanford University Press, 1958, 
Mazur, Ronald. The New Intimacy, Open Ended Marriage and Alternative Lifestyles, Beacon Press, Boston, 1973.

Metz, Charles V. Divorce and Custody for Men, New York, Doubleday, 1968, pp 147

Mindey, Carol. The Divorced Mother, McGraw Hill Book Co., New York, 1969.

Minuchin, Salvador. "Conflict-Resolution in Family Therapy," Psychiatry, Vol 28, 1965, pp 278-286.

Morse, Horace And Paul Dressel Eds. General Education for Personal Maturity, Wm. C. Brown Co., Iowa, 1960.

National Council on Family Relations, Task Force on Divorce and Divorce Reform, Task Force Report, Minnesota, 1974.

Nye, F. Ivan. "Child Adjustment in Broken and in Unhappy, Unbroken Homes," Sourcebook on Marriage and the Family, Edited by Marvin B. Sussman, Houghton Mifflin, 3rd Edition, Boston, Mass, 1968, pp 434-440.

O'Brien, Patricia. The Woman Alone., Quadrangle/The New York Times Book Co, New York, 1973,pp. 278

Oregonian, The. Michigan Judges Claim Reasons for Divorce Remain Obscure," Portland, Oregon, November 16, 1969.

Rheinstein, Max. Marriage Stability, Divorce and the Law, University of Chicago Press, Chicago, 1972.

Santuary, Gerald. Marriage Under Stress, Geo. Allen, Itd. Iondon, 1968

Simon, Anne. The New Years: A New Middle Age, Alfred A. Knopf, Inc.. New York, 1968.

Sprey, Jetse a:, "On the Management of Conflict in Families" Journal of Marriage and the Family, November, 1971 pp $722-730$

Sprey, Jetse, "The Family as a System in Conflict," Journal of Marriage and the Family, November, 1969, pp 699-706.

Seattle Times "Psychologist to Continue Fight for Custody of Daughter" Byline: Larry Brown, Seattle Washington, November $30,1969$.

Steinmetz, Suzanne $K$ and Murry Straus, Eds. Violence in the Family, Dodd Mead \& Co., New York, 1974. 
Steinzor, Bernard. When Parents Divorce, Pocket Books, New York, 1969.

Task Force on Women in Transition, Women's Survival Manual, Penn. 1972.

Taves, Isabella, Women Alone, Funk \& Wagnalls, New York, 1968.

Thompson, Helen, The Successful Stepparent. Harper \& Row, New York, 1966, pp 237.

Tingen vs Tingen Oregon Supreme Court Advance Sheets, Vol. 87. No 5, J. Mengler Author, November 6, 1968, pp $365-368$.

Western Reserve Law Review "The Adversary Process - Child Custody Proceedings", July 18, 1967, pp 1731 - 1752.

Whitehurst, Robert N. "Alternative Iife Styles," The Humanist, Vol XXXV, No. 3, May/June, I975, pp 23-26.

Zuk, Gerald H., Ph.D. "The Go-Between Process in Family Therapy," Family Process, Vol. 5, No. 2, September, 1966. 


\section{FOOTNOTES}

1

William J. Goode, Women in Divorce, The Free Press, New York, 1956 (1965), pp. 1, 12.

2

Erica Abeel, "Divorce Fever: Is It ian Epidemic?" New York, Vol. 7 No.44, November 4., 1974, p. 46.

William D.Brooks, Speech Communication, William C.Brown Co., Iowa, 1971, p. 41. 4

Brooks, p. 143. 5

Daniel Katz, "Psychological Barriers to Communication," Joseph A. DeVito, Ed., Communication Concepts alnd Processes, New Jersey, 1971, p. 173.

Robert B. Macleod, "The Phenomenological Approach to Social Psychology", in Penato Taquire and Iuigi Petrullo, Person Perception and Interpersonal Behavior, (Palo Alto, Stanford University Press, 1958), p. 34.

$$
7
$$

8

Goode, p. 309.

Adrian Bradbsrook, "The Relevance of Psychological and Psychiatric Studies to the Future Development of the Laws Governing the Settlement of Inter-Parental Child Custody Disputes", Journal of Family Law, Vol. 11, p. 560. 9

Rev. Gordon Dickey, Divorced Catholics; An Imperative for Social Ministry, November 1, 1974, p. 13. 10

Jane K. Burgess, "The Single Parent Family: A Social and Sociological Problem", The Family Coordinator, Vol. 19, No. 1 (April, 1970), P. 228. 11

Wendell Johnson and Dorothy Moeller, Iiving with Change: The Semantics of Coping, Harper \& Row, Inc., New York, 1972, p. 17 .

12

Phoebe C. Ellsworth and Robert J. Levy, "Legislative Reform of Child Custody Adjudication", Law and Society Review, 1969, 4:168-233, p. 172 . 13 14

Ellsworth and Levy, pp. 177, 181.

Ivan F. Nye, "Child Adjustment in Broken and in Unhappy, Unbroken Homes". Sourcebook on Narriage and the Family, Edited by Marvin B. Sussman, Boston, Houghton Mifflin, 3rd Edition, 1968, p. 32. 
15

Elizabeth Janeway, Man's World, Woman's Place, A Study in Social Mythology, WiIIiam Morrow \& Company, Inc., New York, 1971, p. 189.

\section{6}

Anne Simon, The New Years: A New Middle Age,

Alfred A. Knopf, Inc., New York, 1968, p. 307.

17

Elizabeth Janeway, quoted in "Annual Report Edition: 1973, Mental Health Association of Oregon, Newsletter (Portiand, October 1973 ). 18

1968) p. 164-5.

Rodney Gorney, M. D., The Human Agenda (New York, 19

David G. Gil, Unravelling Social Policy: Theories, Analysis, and Political Action Toward Social Equality, Mass, $1973, \mathrm{p}, 28$. 20

Walter R. Gove, "Adult Sex Roles and Mental

Illness", American Journal of Sociology, Vol, 78, No. 4, Jähuary, 1973, p. 814 .

21

22

Gove, p. 816.

Janeway, Mental Health Association Newsletter,

October, 1973.

23

Robert N. Whitehurst, "Alternative Life Styles",

The Humanist, Vol. XXXV, No. 3, May/June, 1975, p. 24.

Howard B. Lyman, Ph.D., Single Again,

David McKay Co., Inc., New York, 1971, p. 91. 25

Mel Krantzler, Creative Divorce, M. Evans \& Co., New York, 1973, pp. 92-93. 26

Paul Bohannan, Ed. Divorce After, Doubleday \& Co., Inc., New York, 1971, p. 120. 27 28

Bohannan, p. 297.

National Council on Family Relations, Task Force on Divorce and Divorce Reform, "Task Force Report", Minnesota, 1974, p. 4. 29

David R. Mace, "In Defense of the Nuclear Family", The Humanist, May/June, 1975, p. 29. 


\section{APPENDIX A}


NAME:

ID NUMBER:

ADDRESS :

TELEPHONE NUMBER:

Please write down the name, address and telephone of a relative or friend who will always know where you can be reached.

Name

$$
\text { First }
$$

Middle

Last

Address

Number

Street

City

Zip Code Telephone 
1. How many times have you filed for divorce?

This is the first time I have filed

2 times

3 or more times

2. Race/ethnic identification:

Caucasian, Black (Negro), Chicano (Mexican American), Oriental, Native American (American Indian)

3. Religious preference:

Protestant, Catholic, Jewish, other, None

4. How many children do you have?

Age Sex Grade level School Name Living with
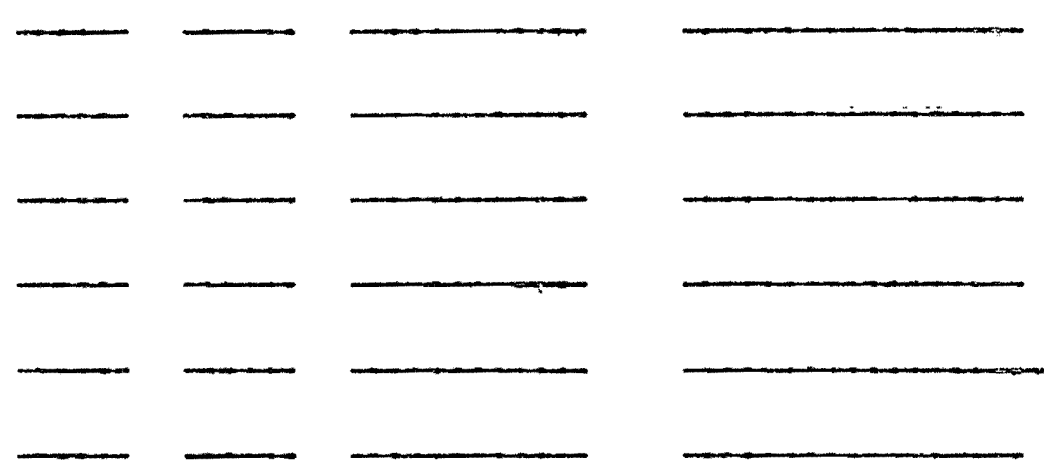

5. Check the following to Indicate those people NOW living with you: No one, Children, Mother and/or Father, Mother-in-law and/or father-in-law, Other relatives, Housekeeper, Friends, other (describe) No 
7. If yes, are you working Ful1 time,

8. What is your occupation?

9. How long have you been working at present job? E: monting 1 - 6 months, 7 - 11 months, 1 - 2 years, more than 2 years

10. If you are not working, how long have you been out of work? Less than 1 month, Between 1 - 6 months, betweel 7 months -1 yr. over 1 year

11. Are you a student or involsed in a work training program? Yes, No.

12. If yes to question $\# 11$, are you involved full time, Part time

13. If no to question \#11, do you plan to seek more schooling or other :raining? Yes, No.

14. What is your work history before marriage? Never morked, worked full time, worked part time.

15. What is your work history during marriage? Never worked, worked full time, worked part tine.

16. How many jobs have gou held during the past five years? None, 1 2 , 3, 4 or more.

17. What is your monthly income before anything is taken out? Le:s than $\$ 200$, $\ldots 200-\$ 399, \ldots \$ 400-\$ 599, \ldots \$ 600-\$ 799, \ldots \$ 800-\$ 999, \ldots \$ 1,006-\$ 199$, $\ldots 1200-\$ 1399, \ldots \$ 1400-\$ 1599, \ldots \$ 1600-\$ 1799, \ldots \$ 1800$ and up

18. If you are working, who takes care of your children on a regular basis? _. Other parent, _. Relatives, _Child care center; __ Baby sitter, Take care of themselves, __ Other (explain) 
19. If you are not working, who takes care of your children when you are away for reasons other than working, such as shopping, appointments, social activities?

Other parent, __ Relatives, ___ Child care center, __ Baby sitter, Take care of themselves.

20. Have you and your spouse talked about living apart? Yes, No.

21. If yes, for how long? L__Less than a week, __ 1 - 3 weeks, _ 1 - 3 months, 4 - 6 months, _over 6 months.

22. Are you and your spouse now living apart? __yes, No. No.

23. If yes, for how long? L_Less than a week, _ 1 - 3 weeks, $1-3$ months, 4 - 6 months, _over 6 months.

24. Have you ever received professional counseling about those problems leading to your divorce? Yes, No

25. Please check to whom you talked about these matters. Psychiatrist Psychologist Counselor/social worker Clergyman Other

26. Are you presently receiving profjessional counseling about those problems leading to your divorce? yes, no

27. Please check to whom you talked about these matters. Psychiatrist Psychologist Counselor/social worker ciergyman other, 
28. Describe briefly some of the reasons you decided co file for divorce.

29. Did you want the divorce? Yes, No.

30. Has the divorce been discussed with your children? yes, no.

31. Who has custody of your children? yourself. spouse, other, (describe)

32. How did you arrive at the decision about who will have custody of your children?

discussed with spouse

_ discussion with children

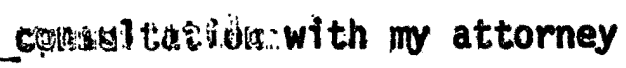

professtonal counseling

court decision

other (describe)

33. What issues were considered in deciding who should have custody of your children?

age of children, ___ sex of children, __wishes of children, ___ schooling for children, __ special health problems, __ child care arrangements, month, relationships of children to parents, __ relationships of parents with other people, ___ remarriage of either parent, ___ other

34. Were any of the following also discussed in deciding who should have custody of your children: work schedule, __ time away from home, __ housing arrangements, _ Outside time commitments, ___ amount of time spent with children. 
35. Did you ever consider any custody arrangement other than the present one. yes, _. no.

36. Are you satisfied with the present custody arrangement? Yes, No

37. What reason (s) would influence you to change the present custody arrangement? change in financial ability to provide by either parent child neglect or abuse by either parent change in either parent's abflity to take care of the children change in living arrangements by either parent that affects the children other

38. Is chlld support lexeing paid? yes, no

39. How did you arrive at the deciston made regarding child support?

discusston with spouse cosultation with my attorney influenced by relatives court decision other (describe)

40. Has a decision been made regarding alimony? yes, no

41. How did you arrive at a decision in regard to alimony?

discussed with spouse

consultation with my attorney

court decision

43. How did you arrive at a decision in regard to visitation arrangements?

discussed with spouse consultation with my attorney professional counseling court decision children's wishes 
44. How frequently do you think visitation should take place? about once a week, more than once a week, _twice a month, every few months, on special occasions or vacations only, never.

45. What do you think is the vaiue of child visitations?

to maintain a contact between parent and child parent has a right to visit the children to help the child feel secure and loved discipline the children to help in other decisions concerning the children other (describe)

46. Do you think the non-custodial parent should take an active role in child rearing? yes, no.

47. If yes, piease check areas in which the non-custodial parent should take an active role.

__school involvement, ___ social activities, ___dress, __ driving, ___ dating, _ discipline, __ allowance, __health, __ religious trainigg, __ use of child support money, __ none, ___ other, (describe)

48. During the divorce proceedings, do you think it would be helpful to have someone sit down with you and your spouse in order to work out a parenting relationship that would be the most beneficlal for your children? yes, No.

49. Have you noticed any change in your children's behavior in any of the following areas? If so, please check. HEALTH:

eating; steeping, complaints of feeling sick, fearfuiness, other 
SCHOOL:

attendance, ___ grades, classroom behavior.

RELATIONS WITH:

brothers \& sisters, _ parents, neighbors, __ playmates \& friends, grand parents, ___ other relatives

I have noticed no changes.

50. Are any of your children in trouble with the police or other juventle authorities?

yes, no no

51. If yes to question $\$ 50$, are they under the supervision of the Juvenile Court or other agency?

yes, _ no, I don't know

52. If yes to question $\$ 53$, what agency is providing supervision?

_Huvenile Court, __ Ghildren Services Division, ___ Maciaren School, Hillcrest School, Youth Care Center, other

53. Have any of your children been in trouble with the police or juvenile authorities in the past? yes, no.

54. If yes to question 53 , what agency sas Juvenile Court, Children Services Division, Maclaren School, HIIIcrest School, ___ Youth Care Center, ___ Other

55. Have any of your children been in any trouble that would ordinarliy lead to contact with police or juvenile authorities? yes, no. no. 


\section{APPENDIX B}




\section{MEMORANDUM}

We would like you to know that the information gathered through this questionnaire will have meaning and will make contribution to the successful outcome of a research project, designed to investigate the impact of divorce on parents and children.

We seek to understand the process involved in reaching the many decisions necessary when a person is divorcing. We are interested in your perception of the process, and there are no judgements being made as to how or why.

The interview will take approximately forty-five minutes to one hour. I would like you to go through the questionnaire and check off the answers as they apply to you, being certain to answer each one.

I will be happy to answer any questions you may have if the meaning is not clear. After you have completed the questionnaire, I will ask you to elaborate on some of the questions and will tape that portion of the interview.

I really appreciate your cooperation. 